\title{
津波の越流に対する海岸堤防の対策法の有効性に関する数值解析
}

\section{Numerical A nalysis of Effectiveness of Countermeasures for Coastal Dikes against Tsunami Overflow}

\author{
中村友昭 ${ }^{1} \cdot$ 根笹裕太 ${ }^{2} \cdot$ 水谷法美 $^{3}$ \\ Tomoaki NA KAMURA, Yuta NEZASA and Norimi MIZUTANI
}

\begin{abstract}
The effectiveness of countermeasures to improve the tenacity of coastal dikes against tsunami overflow is investigated numerically in terms of local scouring at its landward toe and wave force acting on armor blocks. Numerical results show that protection blocks and filter units covering the foundation around the landward toe of the dike move the scouring area landward and reduce its maximum depth, suggesting that these countermeasures would be effective to extend the time before beginning the damage of the body of the dike. It is also revealed that air vents created at the armor blocks reduce an increase in air pressure inside the dike, improving the stability of the armor blocks. Furthermore, it is found that there is no effect of a sheet pile against liquefaction during an earthquake on the local scouring and wave force.
\end{abstract}

\section{1 緒言}

津波に対する海岸保全施設の被害を軽減するために は，設計対象の津波高を超えた場合でも，その効果を粘 り強く発揮できる構造が不可欠である。 三面張構造の海 岸堤防の場合, 小竹・磯部（2012）は法肩に生じる圧力 低下の観点から被覆工の安定性に対する裏法の緩勾配化 の有効性を示している. 鳩貝ら（2012）は, 裏法の緩勾 配化は最大洗掘深の低減の観点からも有効であること, 比高を小さくする対策にも最大洗掘深を抑える効果があ ることを確認している。また，裏法尻に保護工を敷設す ることには, 最大洗掘深の低減に加えて, 洗掘の発生範 囲を堤体から離す効果があることを示している，以上に 加えて, 洗掘に対する裏法面一体型基礎工と地盤改良を 組み合わせた裏法尻の保護の有効性（国土交通省国土技 術政策総合研究所河川研究部, 2012）や, その施工用地 が確保できない場合, 基礎工に矢板を取り付けることで 洗掘発生後の基礎工の移動が抑えられること（加藤ら, 2013）が確認されている．このように粘り強さの効果の 検証が行われてきたものの, 粘り強さを発揮するメカニ ズムに対する検討は十分とは言えない.

本研究では, 洗掘対策として保護工とフィルターユ ニット (以下, FUと略す), 被覆工への作用力低減対策 として空気孔，地震によるせん断変形抑制対策として堤 体内部の矢板に着目する。そそして, 津波の越流による海 岸堤防周辺の洗掘現象を対象とした水理実験との比較に より数值計算モデル（中村・水谷, 2013）の再現性が確 認されていることから（中村ら，2014），その計算モデ

\begin{tabular}{llll}
\hline 1 正会員 & 博(工) & $\begin{array}{l}\text { 名古屋大学准教授 } \\
\text { 会学院工学研究科社 }\end{array}$ \\
2 正会員 & 修(工) & $\begin{array}{l}\text { 東邦ガス株式会社 供給管理部 } \\
3 \text { フェロー }\end{array}$ \\
& 工博 & $\begin{array}{l}\text { 名古屋大学教授 大学院工学研究科社会 } \\
\text { 基盤工学専攻 }\end{array}$
\end{tabular}

ルと計算条件を用いて対策実施後を想定した数值実験を 行い, 各対策法の有効性とそのメカニズムを検討する.

\section{2 計算条件}

本研究では, 移動床の間隙内部の流体を含む非圧縮性 粘性流体からなる全気液相の流体運動を地形の変化を考 慮して解析するメインソルバー, 気液界面を追跡する VOF法に基づくモジュール, 掃流砂・浮遊砂輸送による 地形変化の計算と浮遊砂濃度分布の解析を行うモジュー 儿等から構成される流体・地形変化間の相互作用を解析 できる数值計算モデル（中村・水谷, 2013）を, 縮尺 1/100を想定した中村ら（2014）の水理実験をモデル化し た図-1と図-2に示す計算領域に適用して解析を行った。

図-1に示すように，計算領域内に1/20勾配斜面，1/50勾 配斜面, 水平床からなる不透過海底床を設定し, 水平床 の沖側端に設けた掘り込み（長さ $1.0 \mathrm{~m}$, 深さ $0.22 \mathrm{~m}$ ) 内 に中央粒径 $\mathrm{d}_{50}=0.17 \mathrm{~mm}$ の移動床を敷き詰めた．そして， 図-2に示すように, 厚さ10 mmの不透過材料で被覆され た海岸堤防（天端幅 $0.06 \mathrm{~m}$, 高さ0.08 m, 表法勾配2割, 裏法勾配2割, 中詰材 $0.17 \mathrm{~mm}$ ) を設置した. 静水深は水 平床の表面と静水面が一致する0.76 mとし, 津波をモデ ル化した造波波高0.115 m, 周期37.0 sの引き波初動の長 周期波 1 波を作用させた。 以上の条件に対して, 図-1と図 -2に示すW 1, W6, W 3の位置での水位変動と, 津波作用 後の裏法尻での地形変化の観点から, 水理実験結果との 比較によりモデルの再現性が確認されている. その詳細

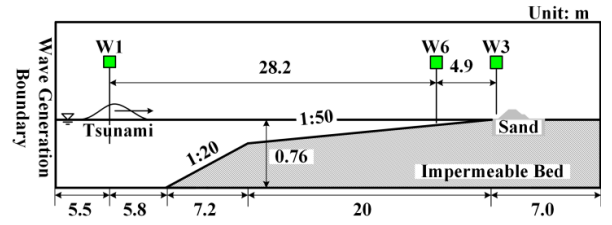

図-1 実験装置の概略図と水位計測位置 (W 1, W 6, W 3) 


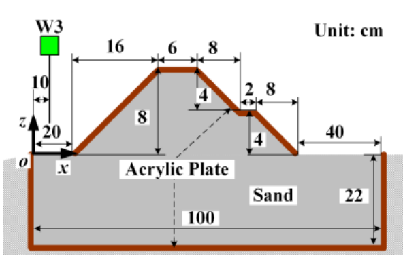

図-2 海岸堤防の概略図

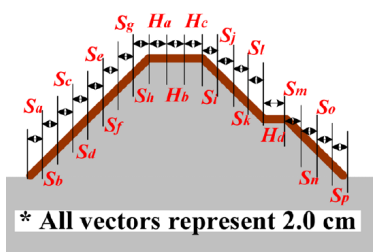

図-5 被覆工の区分け

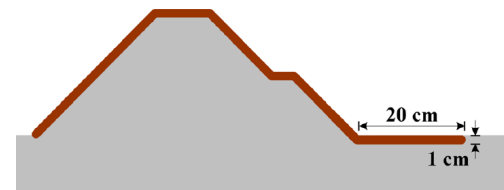

(a) 保護工

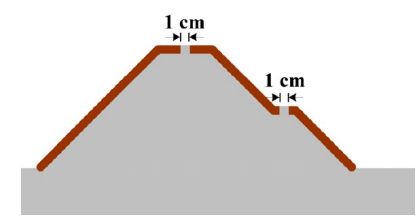

(c) 空気孔

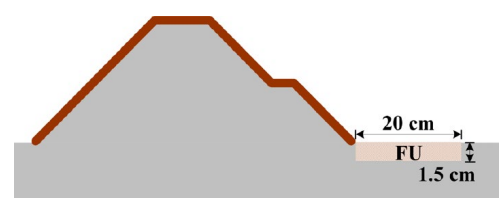

(b) FU

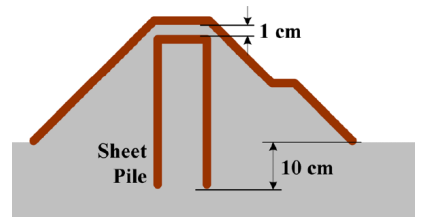

(d) 矢板

図-3 対策工の概略図

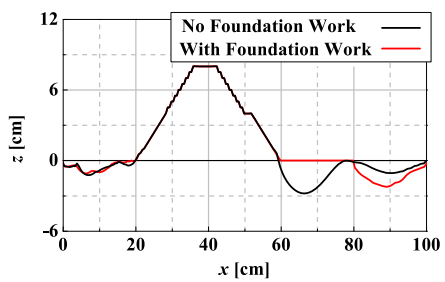

図-4 保護工の有無による津波作用後の地形の比較 の移動床を被覆と同じ厚さ10 mmの不透過材料で置換し た図-3(a) のケースと，出来形の直径が $1.9 \mathrm{~m}$, 高さが0.4 $\mathrm{m}$, 中詰材の中央粒径が100 mmの2 t型FUを約10列3～4層 を想定し長さ $0.20 \mathrm{~m}$, 深さ $15 \mathrm{~mm}$ の移動床を $\mathrm{d}_{50}=10 \mathrm{~mm}$ の材料に置換した図-3(b) のケースを対象とした。また, 被覆工への作用力低減対策として天端と腰掛け部に幅 10 $\mathrm{mm}$ の空気孔を設けた図-3(c) のケースと, 地震によるせ ん断変形抑制対策として堤体の内部に矢板を想定した厚 さ10 mmの逆U字型の不透過材料を埋め込んだ図-3(d) の ケースも対象とした。そして, 上述した図-2の未対策時 を含めて，計5ケースの計算を行った。なお，FUの中詰 材は袋詰めされた状態であることから，FUを構成する $\mathrm{d}_{50}=10 \mathrm{~mm}$ の材料は固定床, すなわち漂砂は生じないも のとした．また，洗掘に伴うFUの移動やFUを通じての 移動床の吸い出しは生じないものと仮定した.

\section{3. 計算結果および考察}

\section{（1）洗掘対策としての保護工の効果}

\section{a) 洗掘への影響}

保護工の有無による津波作用後の地形の比較を図-4に 示す．同図より，保護工未設置時には裏法尻に洗掘が生 じていることが分かる. その一方で, 鳩貝ら（2012）と 同様に，保護工の設置により，洗掘の発生範囲が岸側に ずれ，その最大深さも小さく抑えられていることが確認 できる。 そのため, 保護工には堤防本体が被災するまで の時間を延ばす効果があると示唆される.

\section{b) 被覆工への作用力}

被覆工を図-5に示すように表法8箇所 $\left(S_{a} \sim S_{h}\right)$, 天端3 箇所 $\left(\mathrm{H}_{\mathrm{a}} \sim \mathrm{H}_{\mathrm{c}}\right)$, 裏法の腰掛け部 $\left(\mathrm{H}_{\mathrm{d}}\right)$, 腰掛け部を除く

裏法8箇所 $\left(\mathrm{S}_{\mathrm{i}} \sim \mathrm{S}_{\mathrm{p}}\right)$ の計20箇所に区分けし, 各箇所に作 用する単位長さ，単位奥行き当たりの岸向きを正とする 水平力 $\mathrm{F}_{\mathrm{h}}$ と上向きを正とする鉛直力 $\mathrm{F}_{\mathrm{v}}$ に着目する.

水平力 $\mathrm{F}_{\mathrm{h}}$ と鉛直力 $\mathrm{F}_{\mathrm{v}}$ の時間変化に関して, 未対策時を 図-6に，保護工設置時を図-7に示す。

表法では, 図-6(a) と図-7(a) より, 保護工の有無に 関わらず，天端に近づくほど $F_{n}$ は小さく， $F_{v}$ は大きくな る傾向が確認できる. ただし, 保護工を設置することで, 表法尻の $\mathrm{S}_{\mathrm{a}}$ を除いて， $\mathrm{F}_{\mathrm{h}}$ はより小さく， $\mathrm{F}_{\mathrm{v}}$ はより大きく なっている. これは, 津波越流時の圧力変動Pの分布の 比較を例示した図-8より, 保護工の設置により堤体内部 の空気圧の増加が大きくなったためと考えられる.

同様の理由で, 天端や腰掛け部では, 図-6(b) と図-7 (b) より，保護工を設置することで $F_{v}$ が大きくなる傾向 が確認できる.

また，毫法でも，図-6(c) と図-7(c) に示すように, 裏法尻のS $\mathrm{p}$ を除いて，保護工を設置した方が $\mathrm{F}_{\mathrm{h}}$ や $\mathrm{F}_{\mathrm{v}}$ が大 きくなっている。 ただし，堤体を越流した流れの剥離に より裏法肩周辺の圧力が低下する現象は保護工の有無の 影響を受けなかったことから (図-8参照), 天端において 裏法肩の近くの $\mathrm{H}_{\mathrm{C}}$ に作用する $\mathrm{F}_{\mathrm{v}}$ が他と比べて大きくなる 傾向や，裏法において裏法肩や腰掛け部に近づくほど $\mathrm{h}_{\mathrm{h}}$ やF $\mathrm{v}_{\mathrm{v}}$ 大きくなる傾向は変わらないことが分かる.

なお，図-8に示すように保護工の下部の圧力も上昇して いることから, 鳩貝ら（2012）が指摘しているように，保 護工にも上向きの力が作用していたことを確認している.

以上を踏まえて， 2 七ブロック（縮尺1/100にて寸法13.2 


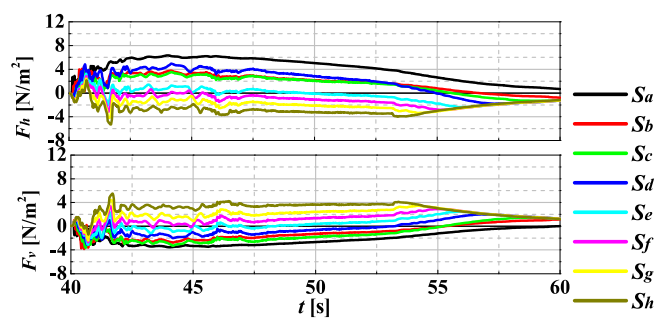

(a) 表法 $\left(\mathrm{S}_{\mathrm{a}} \sim \mathrm{S}_{\mathrm{h}}\right)$

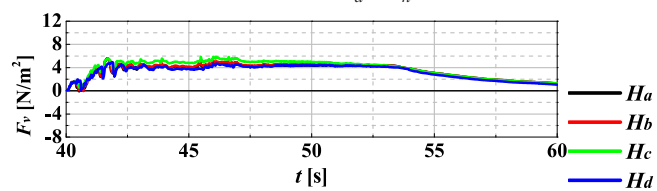

(b) 天端 $\left(\mathrm{H}_{\mathrm{a}} \sim \mathrm{H}_{\mathrm{c}}\right)$ および腰掛け部 $\left(\mathrm{H}_{\mathrm{d}}\right)$

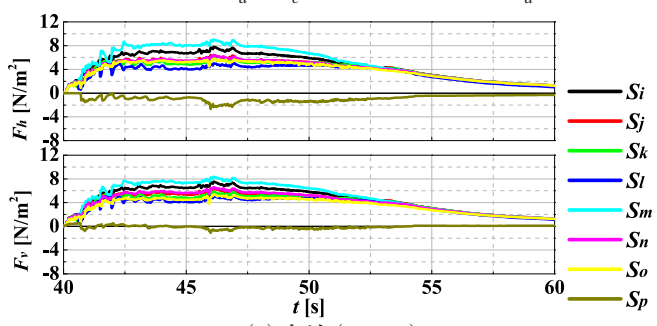

(c) 裏法 $\left(\mathrm{S}_{\mathrm{i}} \sim \mathrm{S}_{\mathrm{p}}\right)$

図-6 未対策時の被覆工への作用力

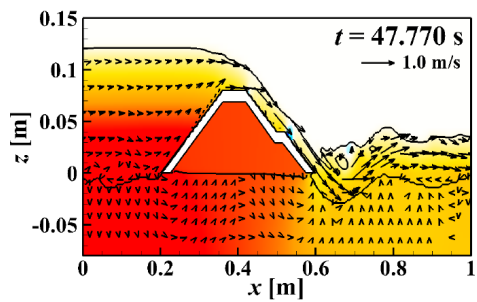

(a) 未対策時

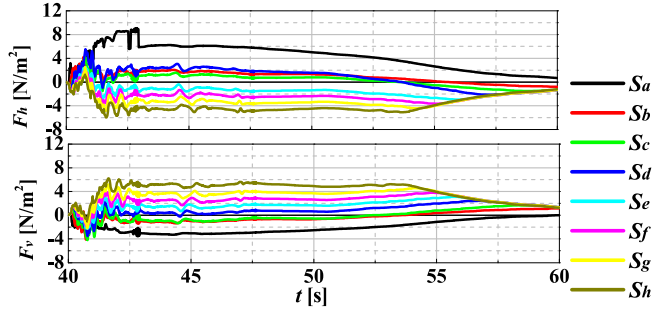

(a) 表法 $\left(S_{a} \sim S_{h}\right)$

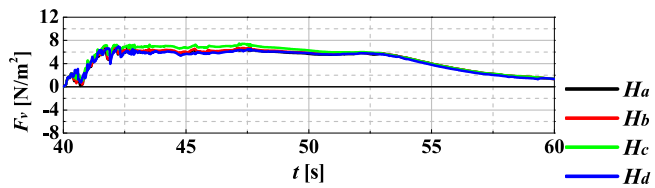

(b) 天端 $\left(\mathrm{H}_{\mathrm{a}} \sim \mathrm{H}_{\mathrm{c}}\right)$ および腰掛け部 $\left(\mathrm{H}_{\mathrm{d}}\right)$

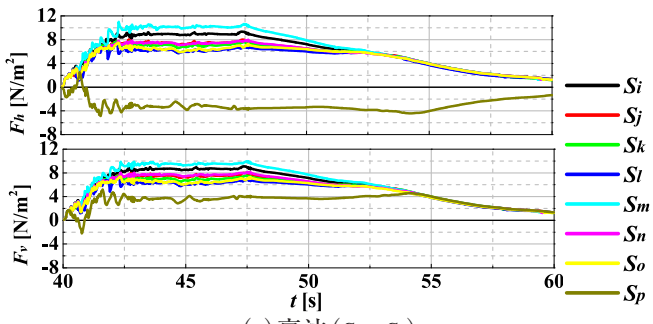

(c) 裏法 $\left(\mathrm{S}_{\mathrm{i}} \sim \mathrm{S}_{\mathrm{p}}\right)$

図-7 保護工設置時の被覆工への作用力

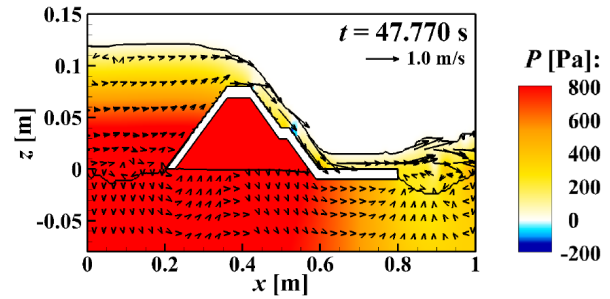

(b) 保護工設置時

図-8 津波越流時の圧力変動Pの分布の比較

x13.2×0.5 mm, 重量2 g）が腰掛け部のすぐ下の $\mathrm{S}_{\mathrm{m}}$ の位置 に設置された状況を想定して，そのブロックに作用する 接線方向の力 $\mathrm{F}_{\mathrm{t}}$ と最大静止摩擦力 $\mathrm{F}_{\mathrm{f}}$ を算出した。 図-9に, ブロックと中詰材の静止摩擦係数を0.6としたとき, 保護 工の有無による $F_{t}$ と $F_{f}$ の時間変化の比較を示す.

図-9より，津波の作用に伴い $\mathrm{F}_{\mathrm{t}}$ が増加するとともに， $\mathrm{F}_{\mathrm{f}}$ が大幅に低下していることが分かる。このとき，保護工 未設置時にはF $\mathrm{F}_{\mathrm{t}}$ 萍を上回る現象はみられないものの, 保護工を設置することで $\mathrm{f}_{\mathrm{t}}$ と $\mathrm{F}_{\mathrm{f}}$ の差が小さくなっている. 特に, $42 \mathrm{~s}$ から $48 \mathrm{~s}$ にかけて $\mathrm{F}_{\mathrm{t}}$ が $\mathrm{F}_{\mathrm{f}}$ を若干上回っており, 被覆工流出の危険性が示唆される.

\section{(2) 洗掘対策としてのFUの効果}

\section{a) 洗掘への影響}

FUの有無による津波作用後の地形の比較を図-10に示 す。同図より，図-4に示した保護工設置時と同様に，洗 掘の発生範囲を堤体本体から離し，その最大深さも低減
させる効果があることが分かる．特に，洗掘の最大深さ は保護工設置時よりも小さく抑えられており，洗掘の防 止効果はFUの方が高いと言える。

\section{b) 被覆工への作用力}

被覆工の各筒所に作用する単位長さ，単位奥行き当た りの水平力 $\mathrm{F}_{\mathrm{h}}$ と鉛直力 $\mathrm{F}_{\mathrm{v}}$ に関して, $\mathrm{FU}$ 設置時の時間変化 を図-11に示す，同図を図-6と比較すると，図-7に示した 保護工設置時と同様に，FUを設置することで，表法では $F_{h}$ の減少と $F_{v}$ の増加, 天端や腰掛け部では $F_{v}$ の増加, 裏 法ではF $\mathrm{h}_{\mathrm{h}}$ と $\mathrm{F}_{\mathrm{v}}$ の増加が生じる傾向が確認できる.

そこで, 2 tブロックが腰掛け部のすぐ下の $\mathrm{S}_{\mathrm{m}}$ の位置に 設置されている状況を想定したとき，そのブロックに作 用する接線方向の力 $\mathrm{F}_{\mathrm{t}}$ と最大静止摩擦力 $\mathrm{F}_{\mathrm{f}}$ の時間変化を 図-12に示す. 同図より， $F_{t}$ と $F_{f}$ の差は図-9(a) に示した 未対策時と比較して小さくなっているものの, 図-9(b) に示した保護工設置時のように $\mathrm{F}_{\mathrm{t}}$ が $\mathrm{F}_{\mathrm{f}}$ を上回ることはな 


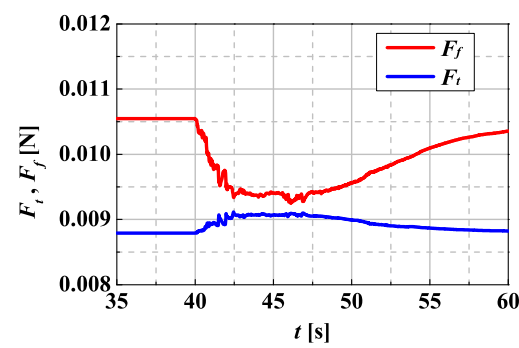

(a) 未対策時

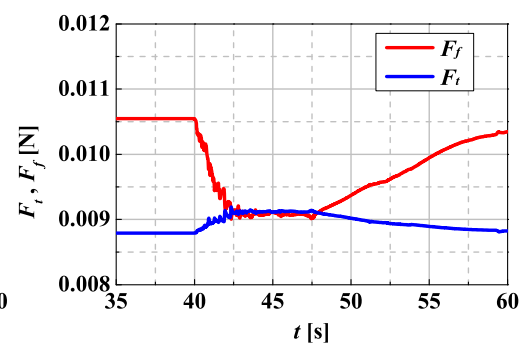

(b) 被覆工設置時

図-9 腰掛け部のすぐ下 $\mathrm{S}_{\mathrm{m}}$ の被覆ブロックに作用する接線方向の力 $\mathrm{F}_{\mathrm{t}}$ と最大静止摩擦力

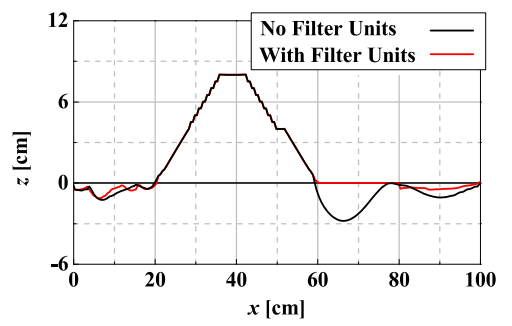

図-10 FUの有無による津波作用後の地形 の比較
$\mathrm{F}_{\mathrm{f}}$ の比較

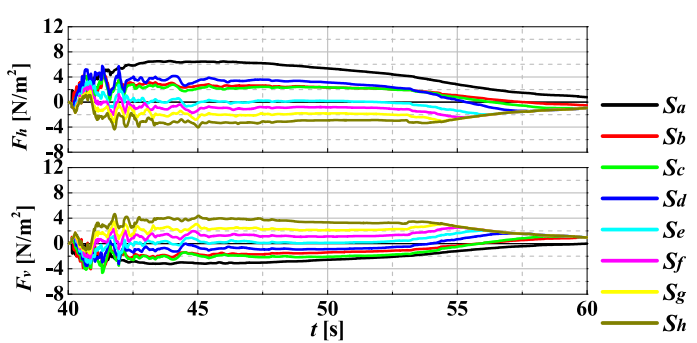

(a) 表法 $\left(S_{a} \sim S_{h}\right)$

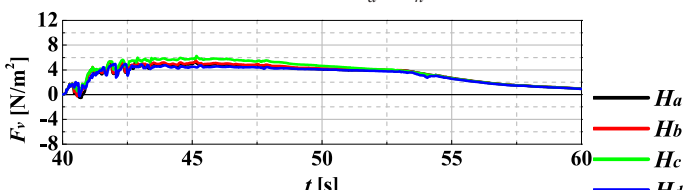

(b) 天端 $\left(\mathrm{H}_{\mathrm{a}} \sim \mathrm{H}_{\mathrm{c}}\right)$ および腰掛け部 $\left(\mathrm{H}_{\mathrm{d}}\right)$

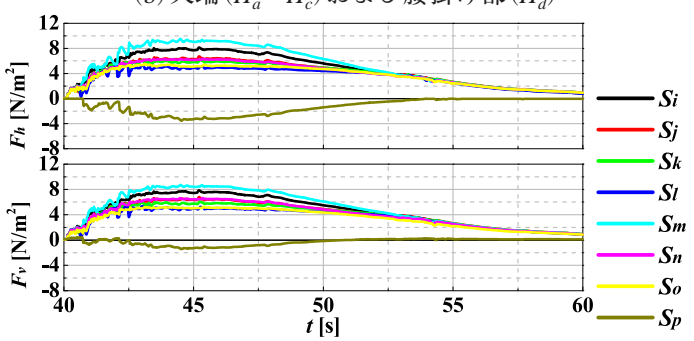

(c) 裏法 $\left(\mathrm{S}_{\mathrm{i}} \sim \mathrm{S}_{\mathrm{p}}\right)$

図-11 FU 設置時の被覆工への作用力

く, 被覆工の安定性に与える影響は保護工よりも小さい ことが示唆される。

\section{（3）被覆工への作用力低減対策として空気孔の効果}

図-13に，被覆工に空気孔を設けたときの $\mathrm{F}_{h}$ と $\mathrm{F}_{\mathrm{v}}$ の時間 変化を示す，同図と図-6の比較より，表法では， $F_{n} か ゙$ 増 加, $F_{\mathrm{v}}$ が減少し, 力の作用方向が岸向きや下向きに変化 したことが分かる．また，裏法では，裏法尻の $\mathrm{S}_{\mathrm{p}}$ での変 化は認められないものの, $F_{h}$ と $F_{v}$ がともに減少し, 岸向 きや上向きに作用する力が低減できている。 これは，津 波越流時の圧力変動Pの分布の比較を例示した図-14よ り，堤体内部に生じる空気圧の上昇が図-8(a) の未対策 時と比較して抑えられたためであると考えられる. 以上 の傾向は, 2 tブロックが腰掛け部のすぐ下の $\mathrm{S}_{\mathrm{m}}$ の位置に

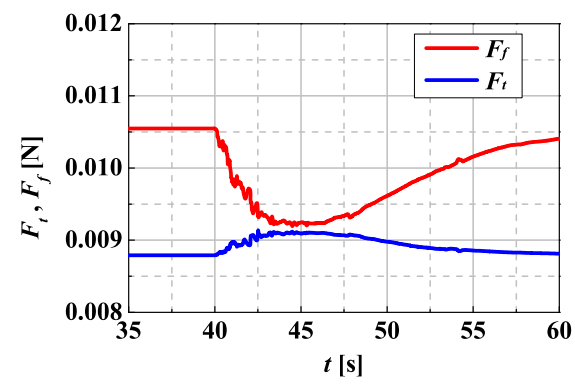

図-12 FU設置時に腰掛け部のすぐ下 $\mathrm{S}_{\mathrm{m}}$ の被覆ブロックに作用 する接線方向の力 $F_{t}$ と最大静止摩擦力 $F_{f}$

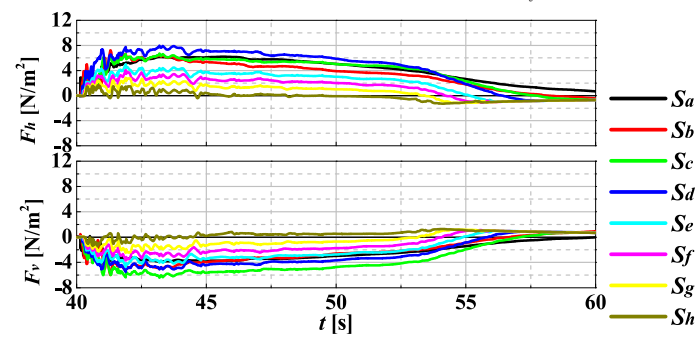

(a) 表法 $\left(\mathrm{S}_{\mathrm{a}} \sim \mathrm{S}_{\mathrm{h}}\right)$

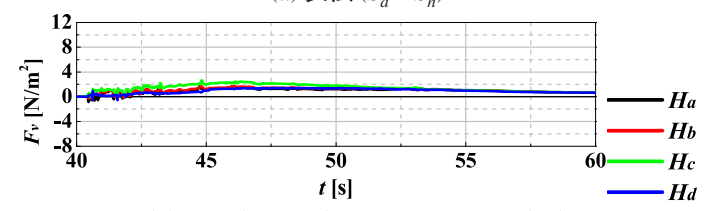

(b) 天端 $\left(\mathrm{H}_{\mathrm{a}} \sim \mathrm{H}_{\mathrm{c}}\right)$ および腰掛け部 $\left(\mathrm{H}_{\mathrm{d}}\right)$

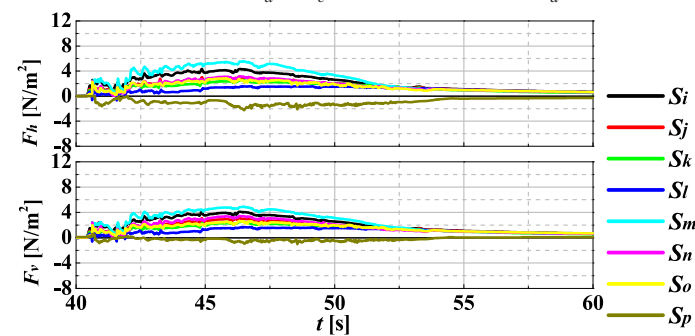

(c) 裏法 $\left(\mathrm{S}_{\mathrm{i}} \sim \mathrm{S}_{\mathrm{p}}\right)$

図-13 空気孔設置時の被覆工への作用力

設置されている状況を想定したとき，そのブロックに作 用する接線方向の力 $\mathrm{F}_{\mathrm{t}}$ と最大静止摩擦力 $\mathrm{F}_{\mathrm{f}}$ の時間変化を 示した図-15からも確認できる.

その一方で, 空気孔の有無による津波作用後の地形の 


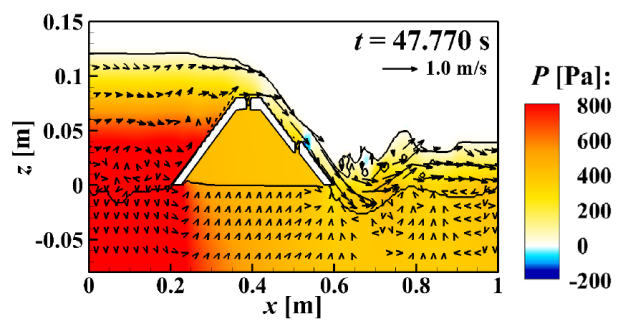

図-14 津波越流時の圧力変動P の分布の比較(空気孔設置時)

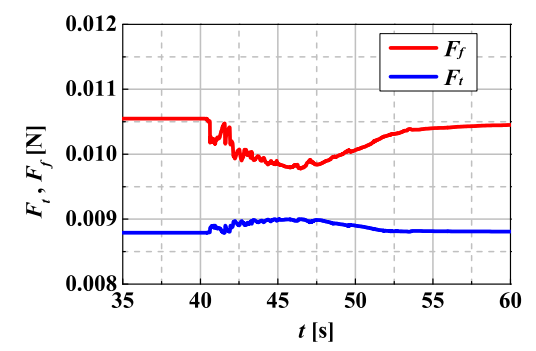

図-15 空気孔設置時に腰掛け部のすぐ下 $S_{m}$ の被覆ブロックに 作用する接線方向の力 $F_{t}$ と最大静止摩擦力 $F_{f}$

比較を示した図-16より, 堤体の岸側に生じる洗掘が若干 浅くなっているものの, 空気孔が洗掘に与える影響は小 さいことが分かる.

（4）地震によるせん断変形抑制対策としての矢板の効果 矢板設置時の裏法の被覆工に作用する $F_{h}$ と $F_{v}$ の時間変 化を図-17に例示する，同図と図-6(c) の比較より，堤体 内部への矢板の設置による顕著な差は認められないこと が分かる。また，図示しないが，矢板の設置が津波作用 後の地形に与える影響は小さいことを確認している.

\section{4. 結論}

本研究では, 津波越流時の海岸堤防を対象に, 洗掘対 策としての保護工とFU, 被覆工への作用力低減対策とし ての空気孔，地震によるせん断変形抑制対策としての堤 体内部の矢板の有効性を数值解析により検討した. その 結果, 得られた主要な結論を以下にまとめる.

（1）保護工の設置には, 洗掘の発生範囲を堤体本体から 離し, その最大深さも低減させる効果が確認でき, 洗 掘対策としての保護工の有效性を示した. その一方で, 保護工を設置することで被覆工の安定性を低下させる 危険性もあることが明らかとなった。

（2）FUの洗掘防止効果は保護工よりも高く, 洗掘刘策と してのFUの有効性が明らかとなった。また，FUの設 置が被覆工の安定性に与える悪影響は保護工の設置と 比較して小さいことが確認できた。 ただし, 洗掘に伴 うFUの移動やFUを通じての移動床の吸い出しは考慮 していないことから，今後はそれらを考慮した検討が 望まれる。

（3）被覆工への空気孔の設置には，堤体内部の空気圧の

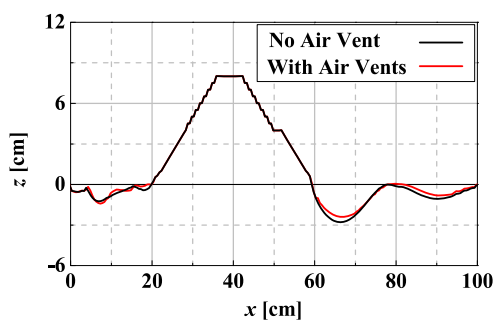

図-16 空気孔の有無による津波作用後の地形の比較

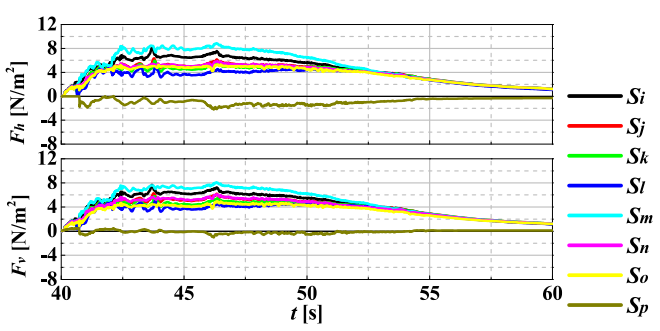

図-17 矢板設置時の裏法被覆工 $\left(S_{i} \sim S_{p}\right) \sim の$ 作用力

上昇を抑制し，被覆工を安定化させる効果が確認でき， 被覆工への作用力低減対策としての空気孔の有効性を 示した

（4）堤体内部への矢板の設置が洗掘や被覆工への作用力 に与える影響は小さく, 洗掘対策や被覆工への作用力 低減対策としての有効性は確認できなかった.

以上の効果は, 水理実験との比較により再現性が検証さ れている条件において確認されたものである。したがっ て，今後は他の条件に対しても水理実験との比較により 再現性の検証を行った上で, 各対策法の有効性を幅広い 条件に対して確認することが望まれる.

最後になるが, 本研究は平成25年度河川砂防技術研究 開発（海岸技術分野）（研究代表者：水谷法美）の補助 を受けたことを付記し，謝意を表する．

\section{参 考 文 献}

国土交通省国土技術政策総合研究所河川研究部 (2012)：粘り 強く効果を発揮する海岸堤防の構造検討 (第2報), 国総 研技術速報, No. 3, 21 p.

加藤史訓・鳩貝 聡・諏訪義雄（2013）：津波の越流に対する コンクリート平張り海岸堤防の粘り強い構造, 土木学会 論文集B3 (海岸工学), Vol.69, No. 2, pp.I_1021-I_1025.

小竹康夫・磯部雅彦（2012）：津波の越流時に海岸堤防の法面 に作用する圧力特性に関する実験的研究, 土木学会論文 集B2（海岸工学), Vol.68, No.2, pp.I_891-I_895.

鳩貝 聡・諏訪義雄・加藤史訓（2012）：津波の越流による海 岸堤防の裏法尻の洗掘に関する水理模型実験, 土木学会 論文集B2 (海岸工学), Vol.68, No. 2, pp.I_406-I_410.

中村友昭・根笹裕太 - 小竹康夫 · 水谷法美 (2014)：海岸堤防 を越流する津波による洗掘の発生機構と被覆工の安定性 に関する研究, 土木学会論文集B2 (海岸工学), Vol. 70, No. 2, pp. I_501-I_505.

中村友昭・水谷法美（2013）：地形変化の影響を考慮した地盤 解析手法の開発とその適用, 土木学会論文集B2（海岸工 学), Vol.69, No.2, pp.I_1026-I_1030. 